\title{
Strategies to Overcome Translation Losses in the Novel "The Grapes of Wrath" by John Steinbeck to Achieve Adequacy in Translation
}

\author{
1, "Konul Khalilova; ${ }^{2}$ Irina Orujova \\ ${ }^{1}$ Khazar University, Azerbaijan; ${ }^{2}$ Azerbaijan Language University, Baku, Azerbaijan. \\ *Corresponding author: konul.khalilova@khazar.org
}

\begin{abstract}
The current article involves the issues of losses, gains or survivals contributing to literature in the process of translation. It represents a thorough study based on a novel "The Grapes of Wrath" by John Steinbeck from English and, respectively, its translation into Azerbaijani by Ulfet Kurchayli. It investigates the problematic areas or challenges emerging from the source-text discrepancies. Furthermore, this article also concentrates on the issue of cultural non-equivalence or the losses occurring in translating English literary texts into Azerbaijani. The paper identifies the translation techniques adopted by the translator of John Steinbeck's The Grapes of Wrath. Adopting certain techniques rather than others has led to many losses on different levels. The translator's important role as a cultural insider is also emphasized. The wide gap, distance or the differences between the cultures, languages and thought patterns of the English and Azerbaijani language speakers are main factors resulting in various losses in the process of translation. Coping with these extra-linguistic constraints is harder than the linguistic ones as the translator has no choice in the given situations, deleting these elements from the TT or replacing them with elements that do not fit the context. This article aims at determining translation losses and gains, defining ways that the translator employs for compensating losses, through the analysis of John Steinbeck's style in The Grapes of Wrath. The article concludes that there are some situations where the translation of a certain text from the SL into the TL embraces alteration in the whole informational content of the text, in the form of expressions or words.
\end{abstract}

Keywords: translation losses, compensatory means, translation procedures, equivalency, transfer operation.

\section{Introduction}

The process of translation between two different written languages involves the translator changing an original written text (the source text or ST) in the original 
verbal language (the source language or SL) into a written text (the target text or TT) in a different verbal language (the target language or TL) (Munday, 2016). The tradition of translation is as old as the tradition of literature. Translation Studies has a long history in many languages including classical languages such as Sanskrit, Greek, Latin, Hebrew, Roman. The classical, literary, religious, political, economic and all other types of texts have been translated into many languages from ancient times till today. But there are many differences among these translated versions of the same text which has become one of the most prominent issues in translating. The rationale of this article is defined by the problems connected with the losses occurring in the process of translation and some different ways used by the translator to compensate for the losses. The term translation can inspire different meanings and connotations. It can refer to the translation of general or technical texts with various themes and genres. It can also refer to the product of the process which is a text or it can be regarded as a term describing a process in a translator's mind that leads to producing a text on paper (Gentzler, 1993).

In Newmark (1981), translation is regarded as the search for how to replace a written message and statement in another language (1981: p.40). It means, to have a quality translation, it must convey the message the writer of the source language intends. It is not necessary to maintain the form of the text as long as the message of the source language can be delivered appropriately to the target language. Catford defines translation as an operation performed on languages which is a process of substituting a text in one language for a text in another (Catford, 1965). He defines translation as a uni-directional process which involves "the replacement of textual material in one language (SL) by equivalent textual material in another language (TL)."

The rationale behind this paper is to analyze all translation procedures used in the novel "The Grapes of Wrath" whereby common mistakes are determined to help avoid such usages by translators in the future. Besides, the translations of the given novel into Azerbaijani have not been yet critically analyzed by previous research.

\section{Reasons Leading to Translation Losses}

The process of translation is decoding a written piece of text from the source language and then encoding the same piece again in the target language where the language of the original writer and context must be taken into consideration. It can be said that translation as an activity arose in ancient times, and it is assumed to be as old as humanity. But, as an academic field of research, it was not known until the second half of the twentieth century. 
Generally, in translation, two kinds of text types can be differentiated: non-literary and literary texts. Non-literary texts refer to a special group of texts which are completely function-specific and conventional in nature and have specific scientific and professional target audience groups with certain features in terms of vocabulary, form and style.

In contrast, non-literary translation covers texts that entail a wide range of topics such as governmental, documentaries, official letters, legal and diplomatic affairs, business administration, news reports, scientific research, manuals, commercial offers, newspaper and magazine articles, advertisements, catalogues, textbooks, web sites, film and television scenarios, restaurant menus, etc.

There are barriers that the translator must overcome to achieve an effective translation. These can be social, historical, political, religious and cultural. Culture has enormous impact on people because it is the foundation of the existence of human beings. Cultural factors can have different sources ranging from formal and linguistic features, ideologies, religion, language or dialect, to art and literacy. Because every community and population has its own indigenous and distinct culture that shapes peoples' perspective about life, culture is understood as the way of life of a people. Their attitudes, values, beliefs, arts, sciences or habits of thought and activity depend on their culture.

Translating deals not just with two languages, but it is a transfer from one culture into another. Since the words and texts to be translated exist in culture, it is very important for the translator to have enough knowledge about the cultures involved in the translation equivalence finding. As such, the social and cultural dimensions challenge the proficiency of the translator and the efficiency of the translation.

The terms social and cultural are assumed to have a connection with each other because cultural activities become meaningful as social significance. Translation is a human activity, and also humans are social, cultural beings, so translation has to have a social, cultural dimension. For this reason, social and cultural factors have an enormous effect on translation.

As language is a cultural construct, a word can be understood as a cultural symbol that provides a specific dimension of meaning in the mind of the source language reader. The difficulty of target readers is that they have a chance to react to such cultural items just in the context of the target language culture. For this reason, the translator should identify the cultural context of the source text in order to be able to explain to the readers the cultural elements used in the work. Therefore, in some cases the translator must use appropriate methods of adjustment such as loan 
translations, explanations and so forth to capture the cultural dimension of the meaning.

Cultural difficulties occur predominantly while translating socio-cultural vocabulary. For instance: idioms and proverbs, myths, folk similies, humour, satire etc. The problem of cultural translation may be seen both in the translation of folk literature and in the case of sophisticated literature.

The political environment of a country may have an enormous impact on how the message is understood or accepted. A number of different categories like religion, elections, wars, and geographical location can affect politics. Politics is considered to be one of the major seats of where translation losses occur.

While translating religious concepts from one religious into another religious framework, many problems are also prone to occurring, which can be very challenging for translators. For example, the word "God", translated into Allah can be a source of controversy to do with if Christians and Muslims believe in the same God. Moreover, stylistics is a major problem when translating holy books.

The historical aspect of translation is also of importance to translators. They should possess deep knowledge of the history of a certain nation in order to convey any nuances lying therein in a smooth style. It becomes easy to understand the historical aspect of the work when it is told in a history-conscious and learned style.

Last but not least, the social factor is another important point to take into account as it has a great effect on people's lifestyle. Social factors can include wealth, buying habits, religion, level of education, family structure, and population density.

All the above-mentioned categories are reasons and potential sources for translation gaps. When any gap or loss occurs, translators come into the picture, so as to prevent translators' job from proving mechanical. They are also the primary interpreters of the meaning intended by author of the source text.

\section{Translation Strategies for Overcoming Translation Losses}

Since languages vary in terms of grammar, structure or morphology, it may become sometimes challenging for translators to transfer the same exact meaning from the source language to the target one, leading to possible gaps occurring on the journey from the SL and TL. In such cases, translators have to use one of the translation techniques below to achieve the same effect in the TL. 
Vinay and Darbelnet's taxonomy of translation procedures used to deal with incompatibilities between SL and TL structures distinguishes two major methods of translation (Vinay \& Darbelnet, 1958):

- A direct translation, which is generally similar to word-by-word translation of the original text in the target language and includes borrowing, calque and literal translation.

- An oblique translation, where the translator interprets, summarizes, and elaborates the explicit contents of the original text in the target language, includes transposition, modulation, equivalence, and adaptation.

\section{Direct/Literal translation procedures}

When there are structural parallelisms between languages, it becomes often possible to cope with translation gaps between the source language and the target language while rendering the source language message piece by piece into the target language. At this point, if the translator notices any gap in the target language, he or she should employ a parallel category or concept to transmit the meaning of the source text unit. This can be achieved with direct translation procedures.

Transference (borrowing) includes loan word, transcription and transliteration. Transcription and transliteration can be understood as rewriting of a text where a certain text from one writing system is transmitted into another writing system. Transcription reflects a foreign language unit based on pronunciation. However, transliteration focuses on presenting correct spelling of the source language word. Borrowing is used to overcome a gap arising as a result of a new technical process or a new concept, achieving stylistic effects and recreating the flavor of the SL in the TL. Calque is a specific type of borrowing where the TL borrows an expression form of the SL by translating each of the original elements word for word.

Literal translation (word for word translation) is based on the direct transfer of a certain text from the source language into the target language. Because of structural and metalinguistic differences between languages, some specific stylistic effects cannot be achieved without changing the lexis or the syntactic order of the TL. In such cases, more complex techniques must be employed to transmit the meaning of the source text. 


\section{Oblique Translation}

Transposition or shift involves replacing one word class with another while keeping the meaning of the source text intact. The shift occurs at the grammatical level; without changing meaning, a certain word class is replaced by another.

Modulation deals with changing the form of the message. The use of modulation may be required in contexts in which a literal translation still sounds awkward in the target language, despite its grammatically correct utterance. Modulation is basically employed in order to produce an accurate or idiomatic text. For using this technique, what is required is an excellent knowledge of both languages involved in the translation.

Equivalence (reformulation) produces an equivalent message in the target language by applying completely different stylistic and structural methods. Reformulation is employed when a simple translation would not be enough to convey the meaning or when literal translation would produce a result which is shocking in the target language or culture. As idioms, clichés, proverbs, nominal or even adjectival phrases, and onomatopoeia cannot be literally rendered, they are mainly transferred using this method of equivalence. Classical examples of such equivalence are to do with the translation of exclamations and expletives. For example, English "Ouch!" corresponds to Azerbaijani "Ahh". Such examples are always practically related to the whole of a message.

Adaptation is used if the type of the situation belonging to the SL does not function in the culture of the target language. In such cases, the translator has to recreate a new situation which can be regarded as almost equivalent to the source language. Four basic types of adaptation can be differentiated including collocation, adaptation, cultural adaptation, literary and ideological adaptation.

\section{Translation Losses and their Impact on Equivalence}

The concept of equivalence holds probably a central position in translation studies. Equivalence is defined as a relation of equal value between source text and target text unit which can occur on any linguistic level ranging from form to function.

Equivalence to a text in another language embraces a number of obstacles including linguistic, temporal and cultural which are quite challenging for translators to tackle. Equivalence suggests producing a target choice that carries an equal value, power, amount, function and meaning to the source text unit. At the same time, it is also used for equal or identical meanings which have the same or similar effects as the 
source text unit. Equivalence has become an essential feature of translation theories. It is pointed out by a number of scholars that there cannot be perfect equivalence between languages. There are several types of equivalence.

Equivalence at word level is considered to be the first element that has to be taken into consideration for finding a direct equivalent unit in the target language. The translator must pay attention to several factors like tense, gender, and number.

With equivalence above word level, each language has, naturally, certain limitations on the combinations of words; in other words, on how they can be combined to render meaning.

Grammatical equivalence means the diversity of grammatical categories through different languages. Many grammatical categories cannot be always expressed in all languages, which influences the process of translation. Consequently, the translators are forced to add or omit information in the target text due to the lack of certain grammatical categories.

Textual equivalence occurs between a source language text and a target language text in terms of coherence and cohesion. The translators' decision to maintain source language coherence or vice versa is basically a question of the target audience, the aim of the translation and type of text.

Pragmatic equivalence has to do more with what is implicit than what is explicit. In other words, the main focus of interest is not about what is explicitly stated but what is intended and implied in a given text and the context and speakers surrounding this textual artefact.

To achieve dynamic equivalence in translation, translators first should be free in their style. The foreign elements in the text must be eliminated by rearranging the structure, word and sentence order of the target text or by modifying and replacing some parts of speech such as noun-pronoun, verb-noun, adjective-verb and so on because the priority is general context of the message.

Formal equivalence is the most used form of equivalence that is also called word for word translation. This means the translator renders verb for verb or noun for noun, thus keeping the sentence and paragraph boundaries of the source text whereby a feel of foreignness is brought into the target text.

Kade highlights four types of directional equivalence (Kade, 1968). These include:

- Total equivalence: There is only one possible equivalent for a source text unit. 
- Zero equivalence: There is no equivalent for a source text unit.

- Approximate equivalence: There are two equivalents for a source text unit.

- Optional equivalence: There are many equivalents for a source text unit.

For this model, functional equivalence is of paramount importance. The first and central aim of the translator is that the translation should have the same communicative function as the ST. Hence the translator must use the same functional style as the source text.

\section{Compensation as a Transfer Operation}

The term loss is strongly connected with compensation. Losses occur when SL element cannot be conveyed into the TL. There are many translations which can be characterized by a series of losses in which many losses occur in a single sentence.

Compensation in translation is one of the standard lexical transfer operations. By means of compensation those meanings of the SL text that are lost in the translating are conveyed in the TL text in another place or by some other means. If it is impossible for translators to create the same effect, then compensation is used for the loss of meaning. Consequently, they achieve creating the same or identical effect in the TT.

The compensation for any effect that is lost in translation is achieved applying different ways. Those ways depend on the type of the loss and also the effort and ability of the translator in order to reduce such a loss. Many translation theorists have presented different classifications for compensation. According to Hervey and Higgins there are four types of compensation: (Hervey \& Higgins, 1992)

Compensation in kind is the first type of compensation which involves making up for a single type of textual effect in the ST by using another type in the TT. It is basically achieved by inserting a specific textual effect into the TT if the effect of the ST cannot be exactly the same reproduced; for instance, Azerbaijani does not express articles as English does, and consequently a translator will need to compensate in kind making a reference somewhere else in the TT which makes this point clear. This type of compensation has three types including keeping kind, changing kind, kind lost.

Compensation in place occurs by shifting textual effect from the exact place. The same effect is found in the TT in a different place either earlier or later. Concerning 
the location of TL compensation four subdivisions of compensation in place can be differentiated: Parallel compensation, contiguous compensation, displaced compensation, compensation by merging.

The last type is compensation by splitting which is obviously opposed to compensation by merging. That consists of conveying one word of a source language into several words in the target text. Compensation by splitting is applied if there is not any word in the target language to cover the identical meaning in the source language.

\section{The Overview of the Language and Style of the Novel "The Grapes of Wrath" by John Steinbeck}

The Grapes of Wrath is an American classic novel by John Steinbeck which is known for its extraordinary descriptive quality. The novel gained this title because of its strong linguistic portrayal techniques and also its socio-economic implications. It was wildly successful to the point that it won even the Pulitzer Prize, the National Book Award and the Nobel Prize for Literature. We should look at the lifestyle and social status of the American community in the Great Depression. After having a deep knowledge about Great Depression and the novel The Grapes of Wrath, one may adequately feel the reflection of this period in the novel.

Before writing the novel, Steinbeck was thinking about a "big book". He made many trips from the Bay Area home to Southern California in order to visit the Arvin Sanitary Camp which was commonly called Weedpatch. John Steinbeck was studying and watching, there in the camp and carefully, the lives of migrant workers. These trips later resulted in a series of 7 essays entitled the Harvest Gypsies published in October 1936 by the San Francisco News. Those essays later were gathered as a single pamphlet entitled Their Blood was Strong. This pamphlet coupled with the articles became the seeds from which the novel the Grapes of Wrath blossomed.

The title of the novel "The Grapes of Wrath" is taken from "the Battle Hymn of the Republic". An abolitionist Julia Ward Howe wrote in 1861 "The Battle Hymn of the Republic", the night after she went to a Union army camp located on the Potomac River near Washington. This hymn was a kind of anthem for the Union soldiers and the abolitionist during the Civil War in America. 
Steinbeck's novel justifies its title through the tale. Grapes in this novel are actually metaphorical. They are the symbol for a new and better life and families full of hope. They symbolically represent rebirth and renewal.

For achieving a greater sense of understanding for the novels, most writers parallel their works with the Bible. The novel The Grapes of Wrath is a Biblical reference to the Book of Revelation as well:

- So the angel swung his sickle to the earth and gathered the clusters from the vine of the earth, and threw them into the great wine press of the wrath of God.

\section{The Investigation of Losses and Compensations in the Translation of "The Grapes of Wrath" into Azerbaijani}

As suggested above, the translator's role is all-important as a cultural insider. The challenges in this regard lead to many losses which influence the interpretation of verbal signs on both the semantic and cultural levels. They are assumed to negatively influence the ways by which the target-text audience understand what the translators have produced. Furthermore, the wide gap, distance or the difference between the cultures, languages and thought patterns of the English and Azerbaijani language speakers are main factors resulting in various losses in the process of translation. The differences existing between the cultures of the SL and TL cause more loss than gain in a language. Coping with these extra-linguistic constraints is harder than the linguistic ones; as the translator has no choice in the given situations, she deletes these elements from the TT or replace them with elements that do not fit the context. Such a decision leads often to explicit and implicit linguistic and cultural losses in the process of translation.

Some examples of losses and compensatory means are going to be analyzed in both source English and target Azerbaijani languages:

EXAMPLE 1:

- SL: “I was a preacher," said the man seriously. Reverend Jim Casy - was a Burning Busher. Used to howl out the name of Jesus to glory (p.14).

- TL: Keçmiş vaiz, - ăgac altında oturmuş adam ciddi dedi - Conab Cim Keysi. Yanmaz sektasından. Olub, olub - Allahın şərəfinə ulamışam (p.21). 
In the first part of the sentence "I was a preacher" is translated as "keçmiş vaiz". The translator used in this part the technique of modulation as Azerbaijani differs structurally from English. Instead of the past simple form of the verb "to be" an adjective "keçmiş" was used in the translated version which can be regarded as the most appropriate variant.

As can be seen in the above sentence in the source text, there is not any expression regarding "ağac altında oturmuş" but the translator added it which is considered a biased addition in the translation. Because anything we add can be done only to compensate losses occuring in the target text.

Reverend is a word usually used in English to describe a respected religious person that has no connotation in Azerbaijani but can be best rendered as "möhtərəm".

In fact, Burning Busher is an allusion to the burning bush in the Biblical book of Exodus, at which Moses was chosen to lead his people out of Egypt. In the novel Jim Casy is a fundamentalist Christian. When Casy was a preacher, God was speaking through him to his listeners. So that "yanmaz sekta" can be accepted at some point as calque translation but is not an accurate translation equivalent.

"Used to" in English is used to express the events in the past that were regularly repeated. As this form is lacking in Azerbaijani, the translator rendered it by repeating the main verb "olmaq".

Although in its literal meaning "howl out" means "ulamaq", it is absolutely inappropriate in this sentence. It could be "səsləmək, çağırmaq". To make the sentence more understandable, it should modified. "Allahın şərəfinə insanları səsləmişəm." would be a better translation.

As has been mentioned before, when word for word translation has awkward shocking results for TL readers, a translator must produce an equivalent text in the target language using completely different stylistic and structural methods. In Christianity, Jesus is accepted for some people God; for others the son of God which could be shocking for Azeri readers as most of them are Muslims. So the translator, in this moment, used reformulation to avoid inaccuracy.

\section{EXAMPLE 2:}

- SL: Your Pa's pa, he quoted Scripture all the time (p.60).

- TL: Ata baban da avvallar bir şey olan kimi Ohdi-cadidi yada salardı (p.91).

The translator translated the word "Scripture" as "Ohdi-cədid" using the method of particularization, in the shared knowledge that the Bible consists of two parts, the 
first of which has also two types; Torah and Psalter. These are considered to be older than the second part of the Bible which is translated into the Azerbaijani language as "Ohdi-ətiq". And the second part of the Bible which is called the New Testament is translated into the Azerbaijani language as "Ohdi-cədid". But the translator should take into consideration that target readers have no information about the parts of the Bible and it would better serve the translator to give a footnote which is a kind of amplification to explain to target readers what this term means.

Moreover, the verb "quote" was translated as "yada salmaq" keeping the general meaning, but it would be more accurate to translate it as "Ata baban da əvvəllər bir şey olan kimi Ohdi-cədiddən sitat gətirirdilər”.

\section{EXAMPLE 3:}

- SL: WHEN THE PORK and potatoes were done the families sat about on the ground and ate, and they were quiet, staring into the fire. Wilson, tearing a slab of meat with his teeth, sighed with contentment. "Nice eatin' pig," he said (p.97).

- TL: Otlə kartof hazır olandan sonra hər iki ailə şam etmək üçün ocaq başına yığışdı.Hamı oturub sakitcə oda baxırdı. Uilson otdən dişləyib razılıqla dedi: Yaxşı atdir (p.147).

The translator used the method of generalisation to translate the noun "pork" and "nice eatin' pig", because pork does not constitute a main part of the target readers' food or culture. The method of compensation was used as well. In the previous paragraph the author writes "The women moved back to the fire to see to supper" (p.97). And the translator translated it as "Qadınlar oradan aralanıb yemək hazırlamaq üçün ocağa yaxınlaşdılar” (p.146).

As "şam yeməyi" was not rendered into the target language, a loss has occurred. The translator added it at another point of the novel using compensation or, more precisely, contiguous compensation. If the loss is compensated within a short distance from the lost effect of the source text, we call it contiguous compensation.

To translate "with contentment" the translator was obliged to use the method of compensation. Because there is no preposition in the Azerbaijani language and the translator used a type of compensation in kind, she rendered it as an adverb.

\section{EXAMPLE 4:}

- SL: But - you see, a bank or a company can't do that, because those creatures don't breathe air, don't eat side-meat. They breathe profits; they 
eat the interest on money. If they don't get it, they die the way you die without air, without side-meat. It is a sad thing, but it is so. It is just so (p.43).

- TL: Banka,yaxud trestə isə başqa şey lazımdır, axı onlar hava ila nəfəs almir, at yemirlar. Onlar galirla nafas alırlar; onlar kapitalın faizlari ila qidalanırlar. Bunlarl vermasən, onlar ölar, neca ki hava ila qidamızı kassalar, biz da sizinla ölarik. Kadarlidir,amma na etmək olar. Başqa çara yoxdur (p.35).

It is seen that the beginning of the sentence "but -you see" has not been rendered to the target text. It could be rendered like "amma bildiyiniz kimi".

- "[...] a bank or a company can't do that, because those creatures don't breathe air, don't eat side-meat."

- "Banka, yaxud trestə isə başqa şey lazımdır, axı onlar hava ilə nəfəs almır, ət yemirlər."

The Azerbaijani word "trest" is equivalent for monopoly. So that instead of "trest" the translator could select "müəssisə, şirkət".

As it is clear, cultural untranslatability occurs due to the absence in the target culture of a relevant situational feature. At this point, the translator must present the aspects of social culture that are unfamiliar to the target readers. So "side-meat" is a type of food which is culturally unstranslatable. The translator has chosen the method of generalization to describe this food.

- "If they don't get it, they die the way you die without air, without side-meat."

- "Bunları verməsən, onlar ölər, necə ki hava ilə qidamızı kəssələr, biz də sizinlə ölərik."

The first part of the sentence has been translated successfully using opposite translation. Because the translator instead of "almaq" has selected "vermək". However, the translator has then turned again to the literal translation method which has led to the complication since the structure of the sentence in the TT does not exist in the ST.

For rendering the given sentence, reformulation could be the best variant. Because an effective transfer of the meaning and the feeling of the text means maximally approximating what the author intended. The following translation is a good example of reformulation: 
- "Bunları verməsən biz havasız, qidasız qalanda necə ölürüksə, onlar da elə ölər."

\section{EXAMPLE 5:}

- SL: Muley's face was smooth and unwrinkled, but it wore the truculent look of a bad child's, the mouth held tight and small, the little eyes half scowling, half petulant (p.43).

- TL: Mülinin üzündə bircə qırış da yox idi, amma arköyün uşaq kimi hirsliydi. Nazik dodaqları kip sıxılmışdı, xırda gözlari tutqun, yaxud asəbi baxırdı (p.35).

The first part of the sentence has been rendered using the negative contrast type of modulation. The word "unwrinkled" has been transferred as "bircə qırış da yox idi", but "smooth" has been omitted which could be translated as "şumal". So the complete sentence could be translated as "Mülinin üzü elə şumal idi ki, bircə qırış da yox idi."

If the second part of the sentence is separately analyzed, inaccuracy in translation can be seen. The translator has added in the Azerbaijani translation an adjective "nazik" which does not correspond to the original version. A better choice would be "kiçik".

The translator has rendered "the little eyes half scowling, half petulant" as "xirda gözləri tutqun, yaxud əsəbi baxırd1." In fact, keeping the meaning and the structure of the sentence, it can best rendered like "xırda gözləri ilə yarı sərt,yarı əsəbi baxirdi".

\section{EXAMPLE 6:}

- SL: And a new unit was formed. The dusk came, but before the dark was down the new family was of the camp. A word had been passed with every family. They were known people-good people (p.43).

- TL: Qaş qaralırd,, lakin taza galanlar hala qaranlaq düşənə qadər düşərganin həyatına daxıl olaraq hər ailayla üç-beş kəlmə kəsməyə imkan tapırdılar.Bunlar özümüzünkülardir, yaxşı adamdırlar (p.35).

In translation of this sentence, a loss has occurred that has great impact in terms of meaning, because unification is one of the central themes of the novel. It could be translated as "Və beləliklə yeni bir qruplaşma yarandı." 
The translator has preferred to render "The dusk came" figuratively that is the main characteristic of literary translation.

The translation of the last sentence is complicated. To approximate an effective translation, one could use "yeni gələn ailələr hərkəs tərəfindən yaxşı insanlar kimi tanınırdı" as the chosen equivalent.

\section{Conclusion}

Translation study is academic and vastly interdisciplinary field that is always progressing. Due to its complexity, variety and vastness, a single universal theory was impossible to be found in the past 50 years.

Loss and compensation are perhaps the most challenging issues in literary translation. As it has already been discussed before, translators must do their best to be faithful to the target audience and text. It can be concluded from this study that compensation techniques are of utmost importance for translating any piece of text from a language into another language. On the basis of the findings, this paper comes to the following conclusions.

When translating literary works, the loss in meaning is considerable due to expressive nature of such texts. To compensate for the lost effect, translators apply compensation as a strategy of translation specifically when it is inevitable. The translators should be careful when using compensation. They have to know first of all which linguistic devices are compensatory, and, second, how the translator can locate an instance of compensation related to a corresponding loss. Last but not least, what counts as an equivalent effect is also critical.

Compensation is successful only if it meets three conditions: necessity, having the same rhetorical result and relevance.

The literature and also the examples provided in this paper and many other studies show that the process of translation is not a substitution of any text between different languages. The translator should be aware of the objectives and also all the meanings conveyed in the ST. If even one shade of meaning is lost during the translation, it means the text rendered in the TL is a failure. For this reason, translation is a task of infinitely challenging proportions and nature, because a poorer or an overly more colorful substitute for the original will fall short of the intended effect and response inter-culturally intended and desired in most cases (Damanhouri, 2018), which might even be a matter of conceptual dissonance between the worldviews entertained by the writer and translator too (Jalalpourroodsari, 2013), all of which are sources of 
challenge that could come into the picture to pose unforeseen problems to the translator too.

\section{References}

Catford, J. C. (1965) A Linguistic Theory of Translation. London: Oxford University Press. Damanhouri, M. (2018). The advantages and disadvantages of body language in Intercultural communication. Khazar Journal of Humanities and Social Sciences, 21 (1), 68-82. DOI: $10.5782 / 2223-2621.2018 .21 .1 .68$

Gentzler, E. (1993). Contemporary Theories of Translation. London and New York: Routledge.

Jalalpourroodsari, M. (2013). Conceptual Dissonance between Thoreau's and Wordsworth's View on Nature and Imagination. Khazar Journal of Humanities and Social Sciences, 16 (3), 5-11. DOI:10.578/2223-2621.2013.16.3.5

Kade, O. (1968) Zufall und Gesetzmäßigkeit der Übersetzung Verlag Enzyklopädie, 128 p. Munday, J. (2016) Introducing Translation Studies: Theories and Applications. 4th edition, Routledge.

Newmark, P. (1981) Approaches to Translation (Language Teaching Methodology Scenes). Oxford: Pergamon Press.

Sándor, H. \& Higgins, I. (1992) Thinking Translation: A Course in Translation Method, French-English. Routledge.

Vinay, J. P. \& Darbelnet, J. (1995) Comparative Stylistics of French and English. Translated and edited by Sager, J. C. and Hamel, M. J. Amsterdam/Philadelphia: John Benjamins. 